\title{
Rancang Bangun Aplikasi Game 3D "KARMA" sebagai Media Mengenal Hukuman dari Perbuatan Buruk Berbasis Android
}

\author{
Ida Ayu Sri Diah Sukayanti, I Ketut Adi Purnawan, AA.Kt.Agung Cahyawan Wiranatha \\ Program Studi Teknologi Informasi, Fakultas Teknik, Universitas Udayana \\ Jalan Raya Bukit Jimbaran, Kabupaten Badung, Bali \\ Telp : (0361) 701806 telp/fax : (0361) 701954, 704845 / (0361) \\ E-mail : gex.zri@gmail.com, adipurnawan@unud.ac.id, agung.cahyawan@unud.ac.id
}

\begin{abstract}
Abstrak
Dosa diartikan sebagai karma atau perbuatan buruk manusia. Dosa merupakan perbuatan yang dilarang oleh Tuhan yang mengakibatkan manusia masuk Neraka. Game 3D "KARMA" dikembangkan bertujuan untuk penyampaian pengetahuan mengenai hukuman dari perbuatan buruk atau dosa. Game 3D "KARMA" dapat membuat pengguna lebih memahami tentang pentingnya berbuat baik dan menghindarkan diri dari perbuatan buruk. Game yang dikembangkan ber-genre side-scrolling running, menampilkan objek 3 Dimensi (3D) dan jenis rintangan berbeda pada setiap gameplay, yang mengangkat cerita dari hukuman yang diterima oleh manusia setelah meninggal, yang melakukan perbuatan buruk semasa hidupnya. Game 3D "KARMA" menggunakan sensor Accelerometer sebagai pengendali karakter menghindari rintangan ke kanan dan ke kiri dengan memiringkan smartphone, yang diimplimentasikan dalam bahasa pemograman C\#. Game 3D "KARMA" yang dihasilkan memiliki 4 level gameplay dengan jenis perbuatan buruk dan hukuman yang berbeda dengan gameplay Level 1 Alam Maya, Level 2 Bukit Gersang, Level 3 Sungai Licin dan Level 4 Jembatan Gantung yang menggunakan objek $3 D$.
\end{abstract}

Kata Kunci: Perbuatan Buruk, Game Edukasi, Accelerometer, 3D, Game Petualangan.

\begin{abstract}
Sin is defined as karma or bad deeds of man. Sin is an act that is forbidden by God that causes man to enter Hell. Game 3D "KARMA" was developed aimed at the delivery of knowledge about the punishment of bad deeds or sin, thus expected users can better understand the importance of doing good and avoid bad deeds. The game developed has a side-scrolling running genre, featuring 3 Dimensional (3D) objects and different types of obstacles on each gameplay, which elevates the story of the punishment received by humans after death, who committed bad deeds during his lifetime. Game 3D "KARMA" uses the Accelerometer sensor as a character controller avoiding obstacles to the right and to the left by tilting the smartphone, which is implemented in $C$ \# programming language. The Game $3 D$ "KARMA" generated has 4 levels of gameplay with different types of bad deeds and penalties different from gameplay Level 1 Alam Maya, Level 2 Gersang Hill, Level 3 Slipstream River and Level 4 Hanging Bridge that uses 3D objects.
\end{abstract}

Keywords: Bad Acts, Educational Games, Accelerometer, 3D, Adventure Game.

\section{Pendahuluan}

Hukum perbuatan sering disebut hukum Karma merupakan sesuatu yang didapat dari hasil perbuatan manusia, termasuk perbuatan buruk atau yang sering disebut dosa. Pengertian dosa sendiri merupakan suatu perbuatan yang dilarang oleh Tuhan yang dapat menjerumuskan manusia menuju Neraka [1]. Semua ajaran Agama yang ada menekankan pada umatnya untuk menghindari melakukan perbuatan buruk atau dosa. Salah satu usaha yang dapat dilakukan terkait pemahaman dosa untuk menghindari manusia dari perbuatan buruk dapat dilakukan melalui penyampaian pengetahuan mengenai hukuman dari perbuatan buruk atau dosa. Usaha penyampaian mengenai beberapa hukuman buruk atau dosa dilakukan pada penelitian ini melalui pengembangan Aplikasi Game 3D "KARMA" dengan tujuan dapat meningkatkan pemahaman terhadap hukuman yang didapat jika melakukan perbuatan buruk atau dosa, 
sehingga diharapkan mendukung pengguna mengikuti ajaran moralitas, yakni selalu berbuat baik dan menjauhi perbuatan buruk atau dosa sehingga dapat terhindar dari Neraka. Penyampainan pengetahuan dapat menjadi lebih menarik dan menyenangkan melalui game dengan menampilkan objek 3D dan melatih ketangkasan pengguna melewati rintangan setiap level-nya. Pengaruh kombinasi teknologi dan pendidikan dianggap sebagai cara untuk kemajuan masyarakat yang berpengaruh besar dalam perbaikan proses pendidikan [2].

Penelitian aplikasi terkait berjudul "Implementation of "Olympic NXT" Android Gaming Application", yang dikembangkan Chandawale, dkk pada Tahun 2014 merupakan Game 3D menggunakan platform Android ber-genre Role Playing Game (RPG) bertujuan membuat permainan menarik dan menghibur dengan objek 3D. Game "Olympic NXT" mengambil empat acara Olympic populer yaitu 100m Sprint, 110m Hurdles, longjump dan Javelin throw yang mempunyai satu karakter sebagai pemain. Karakter menerima tantangan dan mengatasi rintangan untuk menang melalui interaksi dengan rintangan non-playable yang berfungsi sebagai Al. Game "Olympic NXT" memiliki beberapa modul untuk semua objek dan kejadian di dalamnya yang menggunakan bahasa pemograman Java [3].

Penelitian aplikasi game Android yang telah ada sebelumnya memiliki kesamaan tujuan dengan penelitian yang dikembangkan, yaitu menggunakan media game Android dengan genre petualangan edukasi sebagai media pembelajaran yang lebih menarik.dengan judul Aplikasi Game 3D "KARMA" dikembangkan sebagai media pengenalan hukuman dari perbuatan buruk berbasis Android, dengan genre side-scrolling running. Game dibuat menggunakan platform Android dan diimplimentasikan dalam bahasa pemograman $\mathrm{C \#}$ yang menggunakan metode Accelerometer untuk pengendali karakter utama melewati rintangan ke kanan dan ke kiri dan fungsi swipe ke atas pada layar untuk melompat menghindari rintangan. Accelerometer merupakan fitur yang ditanam dalam perangkat smartphone Android [4].

\section{Metodologi Penelitian}

Alur penelitian dalam pembuatan Aplikasi Game 3D "KARMA" sebagai Media Pengenalan Hukuman dari Perbuatan Buruk Berbasis Android dimulai dari tahapan mendefinisikan batasan masalah, mengumpulkan data dan teori-teori dengan studi literatur, mempelajari teknik pembuatan karakter dan animasi objek 3D, penyusunan coding serta pemilihan audio yang sesuai dengan Game 3D "KARMA", selanjutnya instal game yang sudah selesai dalam perangkat Android, serta melakukan pengujian analisis kinerja game untuk mengambil sebuah simpulan.

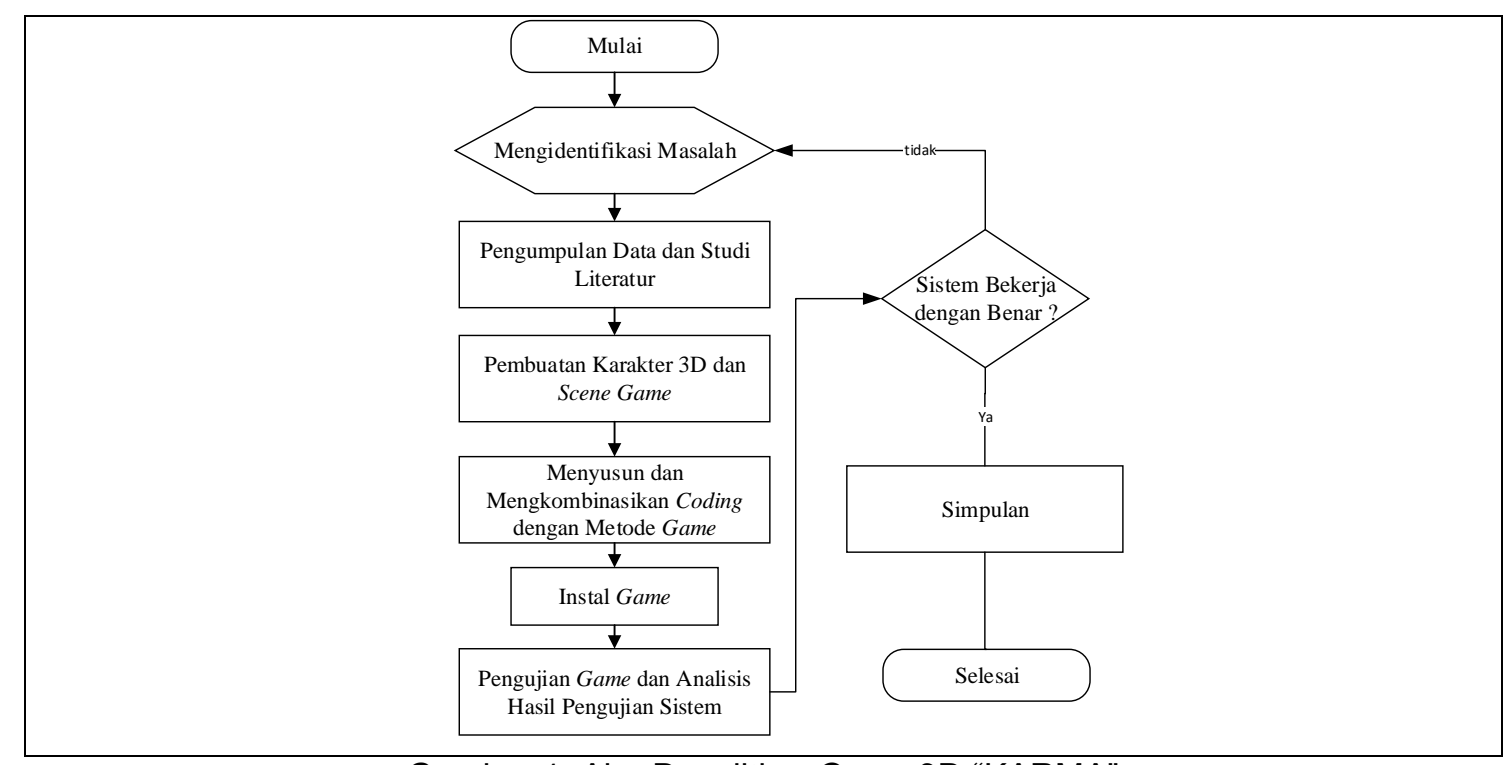

Gambar 1. Alur Penelitian Game 3D "KARMA"

Alur penelitian Game 3D "KARMA" pada Gambar 1 dimulai dari mengidentifikasi masalah dan mengumpulkan data yang digunakan untuk pembuatan karakter 3D dan level dalam game sampai tahap akhir mebuat simpulan. 


\subsection{Gambaran Umum}

Gambaran umum Aplikasi Game 3D "KARMA" sebagai Media Pengenalan Hukuman dari Perbuatan Buruk Berbasis Android yang dikembangkan pada Gambar 2.

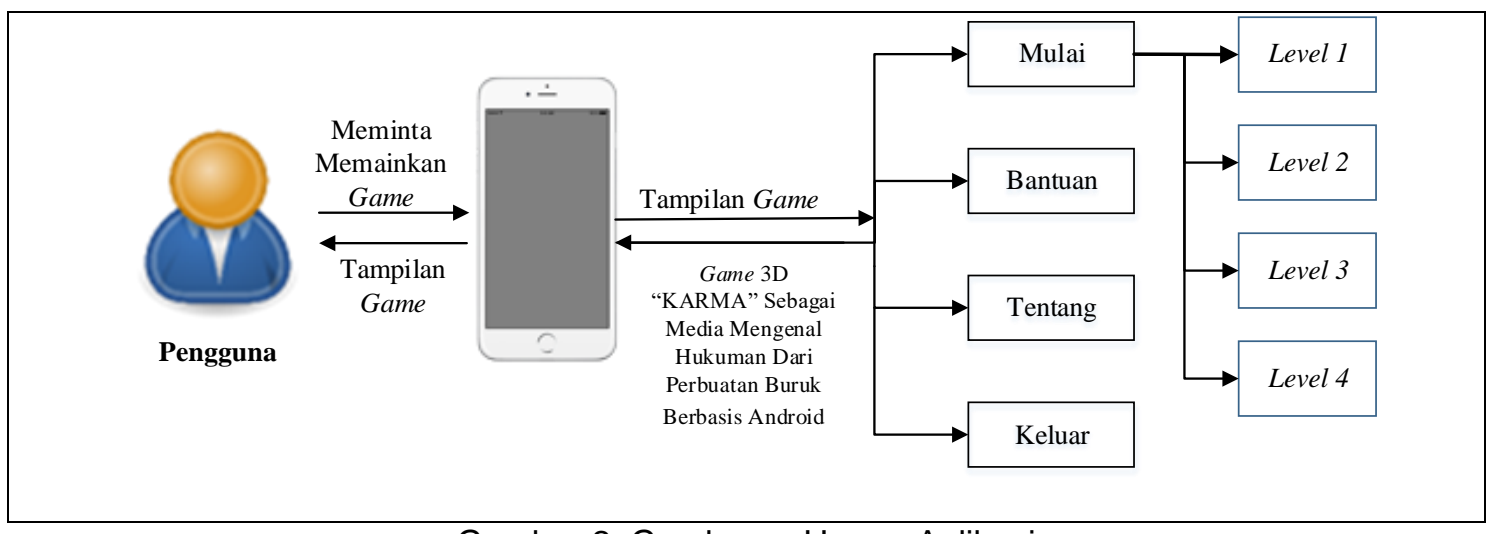

Gambar 2. Gambaran Umum Aplikasi

Gambaran umum aplikasi pada Gambar 2. diawali permintaan memainkan game oleh pengguna pada smartphone yang sudah ter-instal Game 3D "KARMA" sebagai Media Pengenalan Hukuman dari Perbuatan Buruk Berbasis Android. Sistem pada smartphone selanjutnya menampilkan tampilan splashscreen dan tampilan menu utama pada game. Menu utama memiliki empat button, yaitu Button Mulai yang menampilkan menu storyline atau cerita singkat kehidupan karakter utama pada game dan menampilkan Menu Level. Menu level terdapat empat level yang memiliki nama tempat dan rintangan yang berbeda. Nama level 1 Alam Maya, level 2 Bukit Gersang, level 3 Sungai Licin dan level 4 Jembatan Gantung. Button Bantuan menampilkan bagaimana cara bermain dalam bentuk animasi gambar, Button Tentang menampilkan informasi perancang serta latar belakang pembuatan game dan Button Keluar yang berfungsi untuk keluar dari game.

\section{Kajian Pustaka}

Kajian pustaka merupakan teori-teori dasar yang digunakan untuk membentuk Aplikasi Game 3D "KARMA" sebagai Media Pengenalan Hukuman dari Perbuatan Buruk Berbasis Android.

\subsection{Pengertian Perbuatan Buruk}

Karma atau yang sering diartikan sebagai hukum sebab akibat menggambarkan perbuatan buruk, tetapi sebenarnya konsep karma bukan hanya bersangkutan dengan perbuatan buruk melainkan ada karma baik. Perbuatan buruk sering disebut dengan sebutan dosa merupakan perbuatan yang dilarang oleh Tuhan yang membawa manusia masuk menuju Neraka. Melakukan perbuatan buruk membuat manusia mendapatkan sebuah hukuman [1].

\subsection{Game Petualangan Edukasi}

Game yang diartikan dalam bahasa Indonesia adalah sebuah permainan. Permainan merupakan kegiatan kompleks yang memiliki peraturan, gameplay dan budaya. Permainan adalah sistem yang membuat pemain terlibat dalam sebuah konflik buatan yang merupakan rekayasa atau buatan dari perancang [5]. Permainan memiliki banyak genre salah satunya permainan ber-genre petualangan, yang cenderung bersifat kekerasan, maka dari itu permainan ber-genre petualangan diimbangi dengan game edukasi. Beberapa penelitian yang sudah ada terkait genre permainan petualangan disertai edukasi diantaranya penelitian oleh Chandawale, dkk dengan judul Implementation of "Olympic NXT" Android Gaming Application [3], penelitian oleh Adi Ferliyanto dengan judul Augmented Reality Mobile Application of Balinese Hindu Temples DewataAR [6], penelitian oleh Dewa Putu Andre Sanjaya, dkk dengan judul Pengenalan Tradisi Budaya Bali melalui Aplikasi Game Explore Bali Berbasis Android [7], penelitian oleh A. A. Made Arta Wijaya dengan judul Rancang Bangun Game Tajog Race Berbasis Android [8], serta penelitian yang dilakukan oleh Sang Gde Aditya Bhaskara dengan judul Permainan Edukasi Labirin Virtual Reality dengan Metode Collision Detection dan 


\section{Stereoscopic [9].}

\subsection{Sensor Accelerometer}

Sensor Accelerometer merupakan suatu sensor yang dipasang pada smartphone Android, pada dasarnya sensor Accelerometer berfungsi untuk mendeteksi gerakan dalam suatu smartphone berdasarkan pada 3 sumbu yaitu atas-bawah, kanan-kiri dan depanbelakang yang digunakan untuk merubah posisi pada layar smartphone dari posisi landscape menjadi portrait dan sebaliknya [10]. Sensor ini juga memiliki fungsi menentukan derajat kemiringan pada smartphone serta digunakan untuk mengukur percepatan statis dan dinamis suatu objek [4]. Pengukuran dinamis, pengukuran pada pergerakan suatu objek sedangkan pengukuran statis merupakan pengukuran percepatan pada gravitasi, salah satu penerapan pengukuran statis yaitu pada penelitian oleh Wandana Narayana Putra dengan judul Design and Built Interactive Whiteboard Application as Learning Support yang menggunakan fungsi Accelerometer didalamnya [11].

\section{Hasil dan Pembahasan}

Hasil dan pembahasan dalam bab ini membahas tampilan yang dibuat dalam Aplikasi Game 3D "KARMA" sebagai Media Pengenalan Hukuman dari Perbuatan Buruk Berbasis Android

\subsection{Tampilan Aplikasi Game 3D "KARMA"}

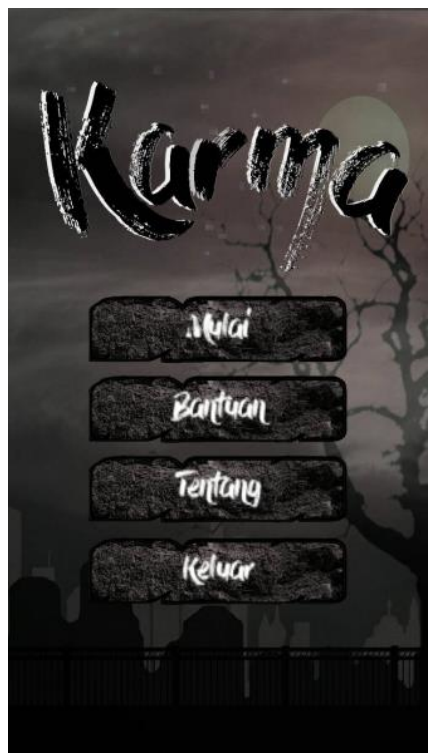

Gambar 3. Tampilan Menu Utama Game

Tampilan Menu Utama pada Gambar 3 merupakan tampilan dari menu utama game yang ditampilkan setelah sistem menampilkan splashscreen dan secara otomatis menampilkan menu utama. Menu utama game memiliki beberapa button yaitu button Mulai, Bantuan, Tentang dan Keluar. Button Mulai merupakan button yang digunakan untuk memulai permainan terdapat Menu Storyline atau cerita singkat kehidupan karakter utama dan menampilkan Menu Level. Button Bantuan menampilkan animasi bantuan atau petunjuk cara bermain untuk membantu pemain. Button Tentang berisikan latar belakang pembuatan game dan informasi tentang perancang, serta ditampilkan Menu Keluar berfungsi keluar dari game. 

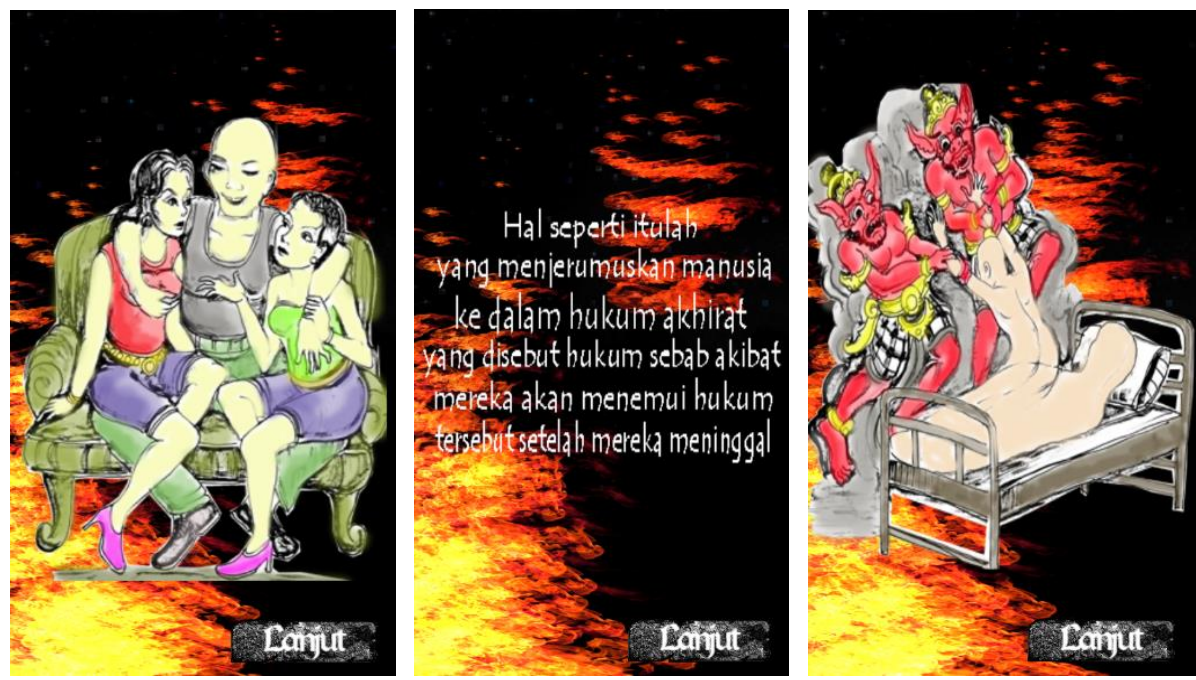

Gambar 4. Tampilan Beberapa Tampilan Storyline

Tampilan storyline pada Gambar 4 merupakan tampilan Menu Storyline atau cerita singkat kehidupan karakter utama pada Game. Storyline dibuat dalam bentuk gambar yang digerakan dalam animasi dengan menggunakan aplikasi Unity. Storyline menceritakan tokoh utama yang memiliki sifat atau perilaku yang buruk semasa hidupnya di dunia, dimana karakter utama melakukan hal-hal yang dilarang oleh Tuhan, setelah karakter utama meninggal roh karakter utama menerima hukuman yang digunakan sebagai gameplay pada Game 3D "KARMA".
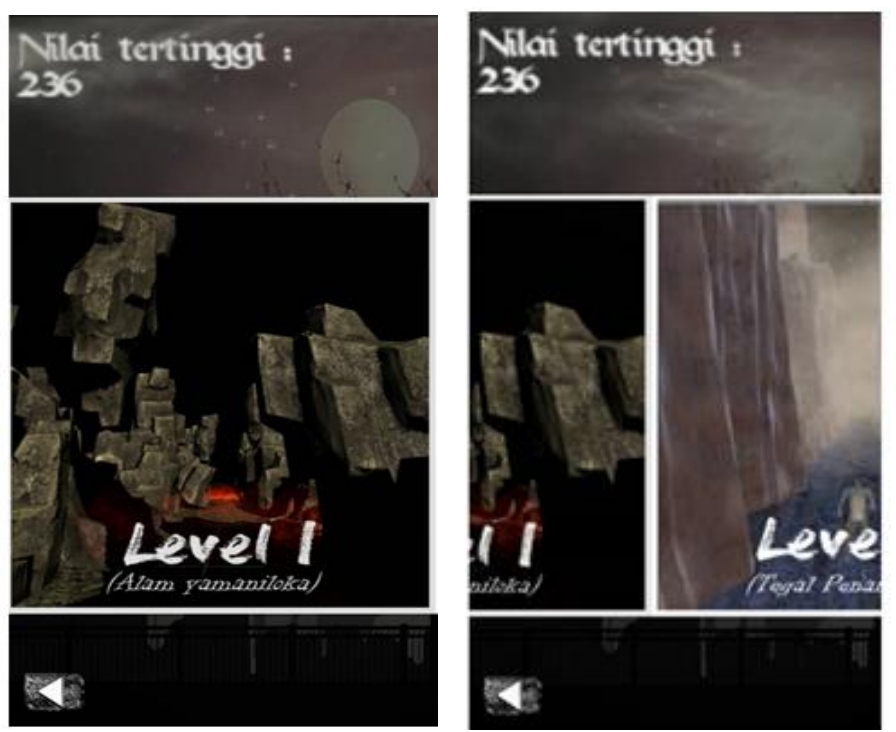

Gambar 5. Tampilan Menu Level

Tampilan Menu Level pada Gambar 5 merupakan tampilan Menu Level pada Game 3D "KARMA" sebagai Media Pengenalan Hukuman dari Perbuatan Buruk Berbasis Android. Menu Level menampilkan Level pada Game yang terdiri dari empat level. Background dan rintangan level dalam game 3D "KARMA" dibuat dalam bentuk 3D, setiap level-nya berbeda-beda jenis rintangan yang ditampilkan. Menu Level juga menampilkan Nilai tertinggi yang didapat pengguna setelah menyelesaikan gameplay. 


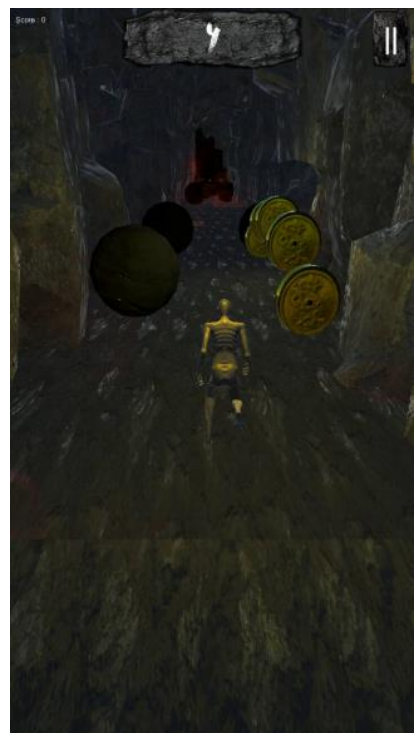

Gambar 6. Tampilan Level Gameplay 1

Tampilan Level Gameplay 1 pada Gambar 6 merupakan tampilan gameplay pada Level 1 Game 3D "KARMA". Level 1 menampilkan background permainan berupa lintasan goa yang gelap dan seram, rintangan di level ini berupa batu besar yang menghalangi karakter utama. Game 3D "KARMA" menggunakan sensor Accelerometer untuk menggerakan karakter utama.

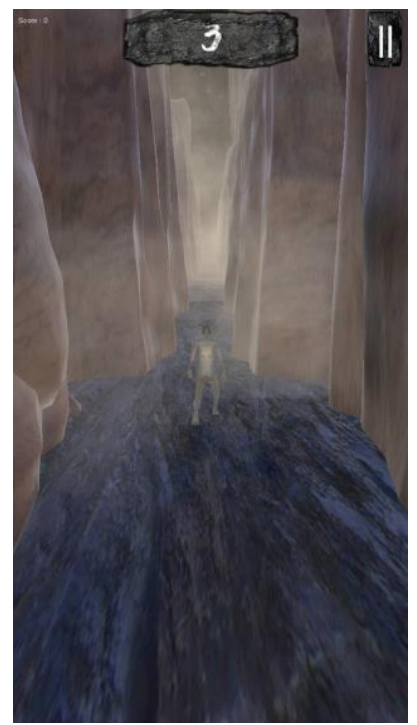

Gambar 7. Tampilan Level Gameplay 2

Tampilan Level Gameplay 2 pada Gambar 7 merupakan tampilan gameplay pada Level 2 Game 3D "KARMA". Level 2 menampilkan background permainan sebuah lintasan dengan kanan kiri terdapat tebing yang tinggi rintangan di level ini berupa tebing yang menghalangi karakter utama. Game 3D "KARMA" menggunakan sensor Accelerometer untuk menggerakan karakter utama. 


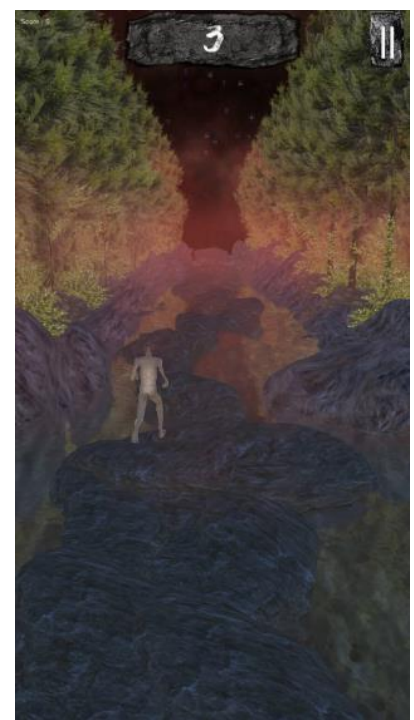

Gambar 8. Tampilan Level Gameplay 3

Tampilan Level Gamplay 3 pada Gambar 8 merupakan tampilan gameplay pada Level 3 Game 3D "KARMA". Level 3 menampilkan background lintasan sebuah sungai dengan pijakan licin di tengah dan kiri kanan lintasan terdapat pepohonan 3D menyerupai hutan, rintangan di level ini berupa pijakan yang licin sehingga karakter utama harus menjaga keseimbangan. Game 3D "KARMA" menggunakan sensor Accelerometer untuk menggerakan karakter utama.

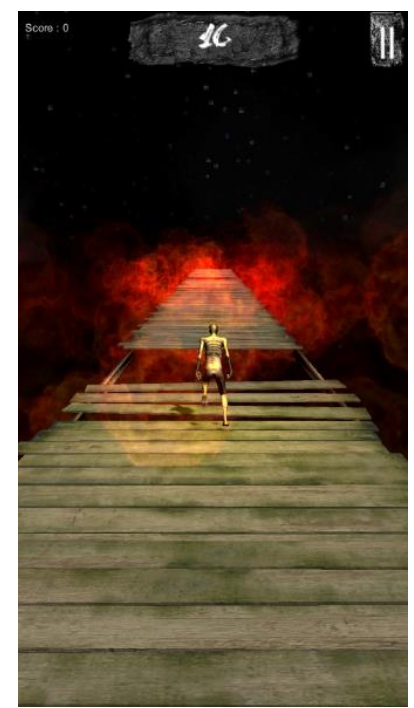

Gambar 9. Tampilan Level Gameplay 4

Tampilan Level Gameplay 4 pada Gambar 9 merupakan tampilan gameplay pada Level 4 Game 3D "KARMA". Level 4 menampilkan background permainan sebuah jembatan yang rusak tidak ada pembatas pada kanan kiri jembatan, rintangan di level ini berupa jembatan yang rusak atau runtuh sehingga karakter utama harus menjaga keseimbangan agar tidak jatuh dan lompat pada jembatan yang rusak. Game 3D "KARMA" menggunakan sensor Accelerometer untuk menggerakan karakter utama.

\subsection{Penilaian Kuesioner}


Penilaian kuesioner Game 3D "KARMA" sebagai Media Pengenalan Hukuman dari Perbuatan Buruk Berbasis Android berisikan tampilan diagram pie dan persentase hasil penilaian yang dilakukan pada responden.

\subsubsection{Analisis Sistem Aplikasi}

Analisis pada Game 3D "KARMA" digunakan untuk menguji kriteria kelayakan aplikasi menggunakan metode survei yang memiliki beberapa aspek yaitu Aspek Pengalaman Pengguna, Aspek User Interface Game, Aspek Rekayasa Perangkat Lunak, Aspek Entertaiment Game dan Aspek Content Game. Pengambilan survei terkait pengujian dilakukan dengan menggunakan kuesioner yang dibagikan kepada 60 responden kalangan umum.

\subsubsection{Aspek Pengalaman Pengguna}

\section{Aspek Pengalaman Pengguna}

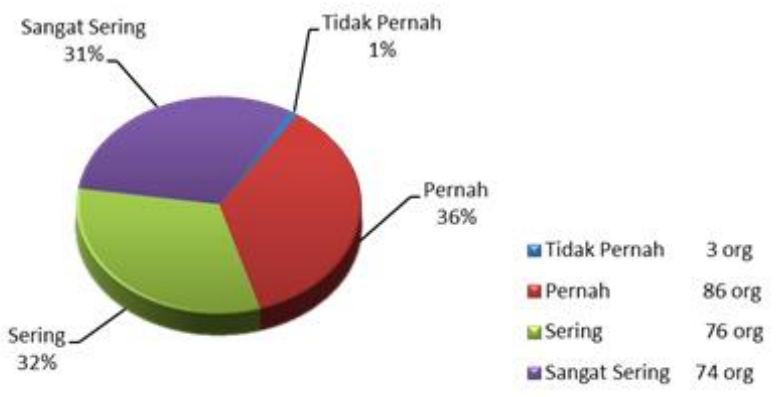

Gambar 10. Aspek Pengalaman Pengguna

Diagram pie pada Gambar 10 merupakan grafik pie presentase nilai pada Aspek Pengalaman Pengguna dari Game 3D "KARMA" sebagai Media Mengenal Hukuman dari Perbuatan Buruk Berbasis Android. Presentase nilai pada Aspek Pengalaman Pengguna menunjukan tergolong sangat sering dengan presentase $31 \%$, penilaian tergolong sering menunjukan presentase $32 \%$, penilaian tergolong pernah dengan presentase $36 \%$ dan tergolong tidak pernah dengan presentase 1\%. Berdasarkan presentase Aspek Pengalaman Pengguna dapat disimpulkan pengguna $99 \%$ pernah memainkan Game ber-gendre petualangan edukasi side-scrolling running.

\subsubsection{Aspek User Interface Game}

Aspek User Interface Game

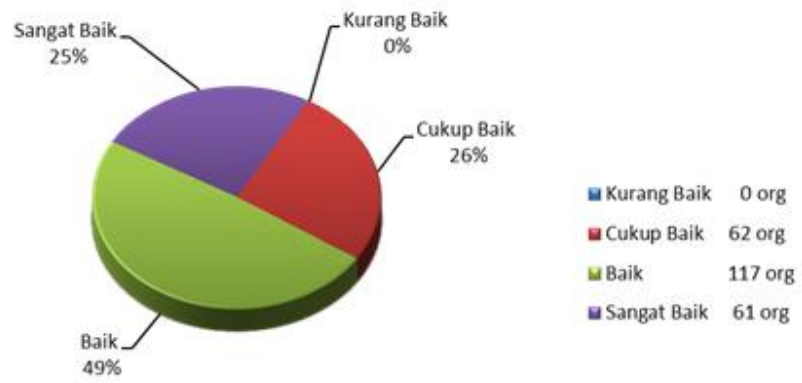

Gambar 11. Aspek User Interface Game

Diagram pie pada Gambar 11 merupakan tampilan grafik pie presentase nilai pada Aspek User Interface Game dari Game 3D "KARMA" sebagai Media Mengenal Hukuman dari Perbuatan Buruk Berbasis Android. Presentase nilai pada Aspek User Interface Game menunjukan tergolong sangat baik dengan presentase $25 \%$, penilaian tergolong baik menunjukan presentase $49 \%$, penilaian tergolong cukup baik dengan presentase $26 \%$ dan tergolong kurang baik dengan presentase 0\%. Berdasarkan presentase Aspek User Interface 
Game dapat disimpulkan tampilan background, warna, audio dan animasi yang terdapat pada Game 3D "KARMA" sudah baik.

\subsubsection{Aspek Rekayasa Perangkat Lunak}

\section{Aspek Rekayasa Perangkat Lunak}

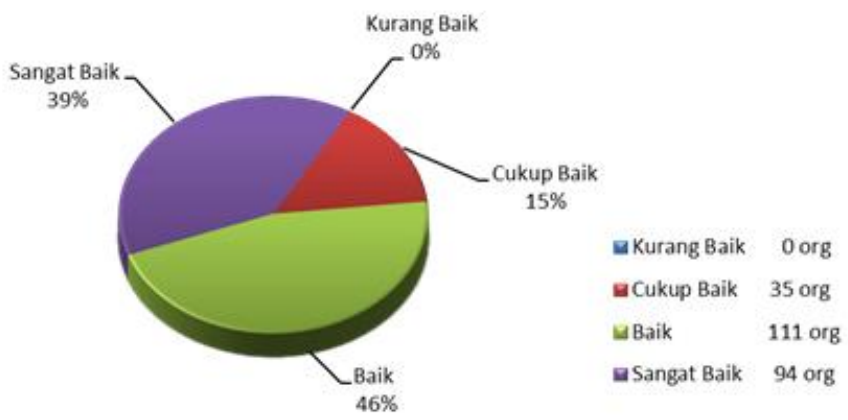

Gambar 12. Aspek Rekayasa Perangkat Lunak

Diagram pie pada Gambar 12 merupakan tampilan grafik pie presentase nilai pada Aspek Rekayasa Perangkat Lunak dari Game 3D "KARMA" sebagai Media Mengenal Hukuman dari Perbuatan Buruk Berbasis Android. Presentase nilai pada Aspek Rekayasa Perangkat Lunak menunjukan tergolong sangat baik dengan presentase $39 \%$, penilaian tergolong baik menunjukan presentase $46 \%$, penilaian tergolong cukup baik dengan presentase $15 \%$ dan tergolong kurang baik dengan presentase $0 \%$. Berdasarkan presentase Aspek Rekayasa Perangkat Lunak dapat disimpulkan kehandalan, fungsi antara menu Game 3D "KARMA" sudah baik dan game 3D "KARMA" sudah bersifat user friendly.

\subsubsection{Aspek Entertaiment Game}

\section{Aspek Entertaiment Game}

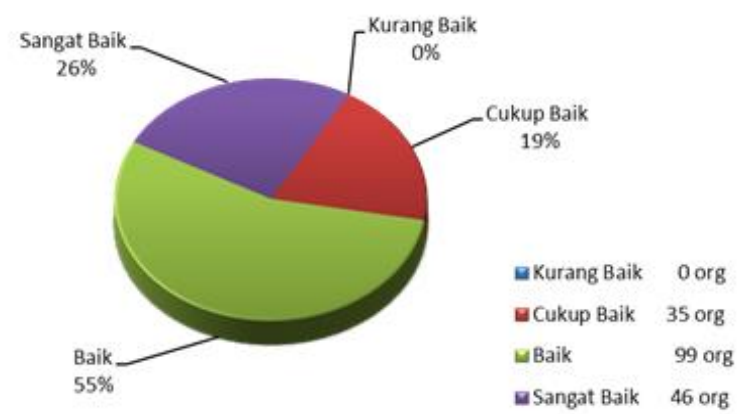

Gambar 13. Aspek Entertaiment Game

Diagram pie pada Gambar 13 merupakan tampilan grafik pie presentase nilai pada Aspek Entertaiment Game dari Game 3D "KARMA". Presentase nilai pada Aspek Entertaiment Game menunjukan tergolong sangat baik dengan presentase $26 \%$, penilaian tergolong baik menunjukan presentase 55\%, penilaian tergolong cukup baik dengan presentase $19 \%$ dan tergolong kurang baik dengan presentase 0\%. Berdasarkan presentase Aspek Entertaiment Game dapat disimpulkan bahwa Game 3D "KARMA" mampu menjadi media pengenalan hukuman dari perbuatan buruk manusia yang menarik dan menyenangkan untuk pengguna.

\subsubsection{Aspek Content Game}


Aspek Content Game

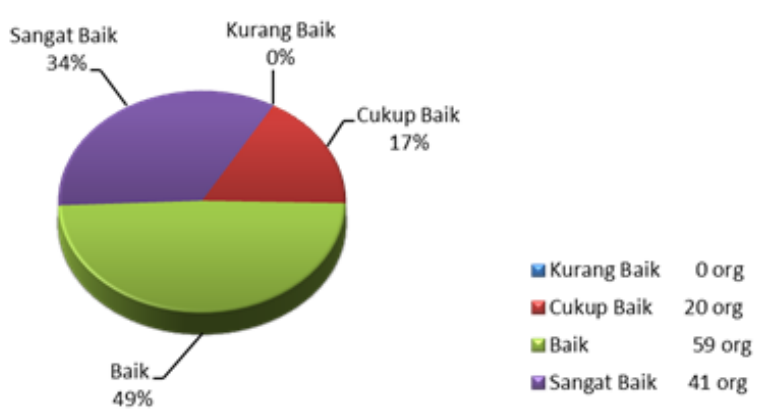

Gambar 14. Aspek Content Game

Diagram pie pada Gambar 14 merupakan tampilan grafik pie presentase nilai pada Aspek Content Game dari Game 3D "KARMA". Presentase nilai pada Aspek Content Game menunjukan tergolong sangat baik dengan presentase $34 \%$, penilaian tergolong baik menunjukan presentase $49 \%$, penilaian tergolong cukup baik dengan presentase $17 \%$ dan tergolong kurang baik dengan presentase 0\%. Berdasarkan presentase Aspek Content Game dapat disimpulkan gameplay dalam Game 3D "KARMA" sudah sesuai dengan alur cerita atau storyline.

\section{Simpulan}

Game 3D "KARMA" yang telah dibuat dengan genre game petualangan edukasi mampu meningkatkan pemahaman pengguna terhadap hukuman yang didapat jika melakukan perbuatan buruk atau dosa. Gameplay setiap level menampilkan bagaimana bentuk- bentuk hukuman yang didapat, dibuat sesuai dengan jenis perbuatan buruk yang dilakukan. Tampilan objek 3D dan rintangan ditampilkan dalam gameplay dibuat menggunakan imajinasi perancang dibuat sedemikian rupa agar permainan menarik dan menyenangkan seperti, tampilan background dan rintangan $3 \mathrm{D}$ dibuat dengan efek dan tekstur menyerupai suasana dalam Neraka yang panas dan gelap. Game 3D "KARMA" menggunakan fungsi sensor Accelerometer untuk menggerakkan karakter utama ke kanan dan ke kiri dan fungsi swipe atas untuk lompat menghindari rintangan pada setiap level. Game menggunakan platform Android yang diimplementasikan dalam bahasa pemograman C\#. Hasil penilaian Game dapat dilihat pada hasil presentase pada aspek content game dengan presentase baik yang mencapai $49 \%$ dan sangat baik 34\% dengan simpulan Game 3D "KARMA" memiliki gameplay sesuai dengan alur cerita atau storyline yang bisa meningkatkan pemahaman terhadap hukuman yang didapat jika melakukan perbuatan buruk atau dosa, sehingga diharapkan pengguna mampu untuk berbuat baik.

\section{Daftar Pustaka}

[1] Ayu Rini, Dosa Menurut Hindu (Batasan Umat dalam Bertingkah Laku Demi Mencapai Moksha). Surabaya, 2011.

[2] I. K. Sudarsana, "Peningkatan Mutu Pendidikan Luar Sekolah dalam Upaya Pembangunan Sumber Daya Manusia," Jurnal Penjaminan Mutu, vol. 1, no. Volume 1 Nomor 1 Pebruari 2015, pp. 1-14, 2015.

[3] S. Chandawale, N. Kapoor, S. Bane, A. Jadhav, and P. A. Raut, "Implementation of " Olympic NXT ' Android Gaming Application," International Journal of Advanced Research in Computer Science and Software Engineering, vol. 4, no. 3, pp. 617-620, 2014.

[4] N. Luh, C. Darmayanti, I. K. A. Purnawan, and P. W. Buana, "Rancang Bangun Game Edukasi Perjalanan Dang Hyang Nirartha di Bali," MERPATI, vol. 5, no. 2, pp. 23-33, 2017.

[5] I. W. Widarma, E. Putra, A. A. K. Agung, C. Wiranatha, and I. N. Piarsa, "Rancang Bangun Game Tradisional ‘ Adu Gasing ' pada Platform Android," MERPATI, vol. 4, no. 2, pp. 178-187, 2016.

[6] Wahyu Pratama, "Game Adventure Misteri Kotak Pandora," Jurnal Telematika, 18, vol. 
7, no. 2, pp. 13-31, 2014.

[7] A. F. Waruwu, I. P. A. Bayupati, and I. K. G. Darma Putra, "Augmented Reality Mobile Application of Balinese Hindu Temples : DewataAR," IJCSI International Journal of Computer Science Issues, no. 1 January, pp. 59-66, 2015.

[8] D. P. A. Sanjaya, I. K. A. Purnawan, and N. K. D. Rusjayanthi, "Pengenalan Tradisi Budaya Bali melalui Aplikasi Game Explore Bali Berbasis Android," LONTAR Komputer., vol. 7, no. 3, pp. 162-173, 2016.

[9] A. A. M. A. Wijaya, I. K. A. Purnawan, and K. S. Wibawa, "Rancang Bangun Game Tajog Race Berbasis Android," MERPATI, vol. 4, no. 2, pp. 166-177, 2016.

[10] S. G. A. Bhaskara, P. W. Buana, and I. K. A. Purnawan, "Permainan Edukasi Labirin Virtual Reality dengan Metode Collision Detection dan Stereoscopic," LONTAR Komputer., vol. 8, no. 2, pp. 65-76, 2017.

[11] W. N. Putra, I. A. A. Ketut, A. Cahyawan, and N. Piarsa, "Design and Built Interactive Whiteboard Application as Learning Support Using Game Controlling," IJCSI International Journal of Computer Science Issues, vol. 10, no. 2, pp. 480-485, 2013. 